\title{
Lobomycosis-like disease and other skin conditions in Indo-Pacific bottlenose dolphins Tursiops aduncus from the Indian Ocean
}

\author{
Jeremy Kiszka $^{1,2, *}$, Marie-Françoise Van Bressem ${ }^{3}$, Claire Pusineri $^{4}$ \\ ${ }^{1}$ University of La Rochelle, LIENSS (Littoral, Environnement et Sociétés), UMR 6250 CNRS-Université de La Rochelle, \\ 2 rue Olympe de Gouges, 17000 La Rochelle, France \\ ${ }^{2}$ Direction de l'Environnement et du Développement Durable, Conseil Général de Mayotte, BP 101, 97600 Mamoudzou, \\ Mayotte, France \\ ${ }^{3}$ Cetacean Conservation Medicine Group (CMED), CEPEC, Museo de Delfines, Pucusana, Peru \\ ${ }^{4}$ Office National de la Chasse et de la Faune Sauvage, Cellule Technique Océan Indien, Coconi, Mayotte
}

\begin{abstract}
Lobomycosis is a chronic mycotic disease of the skin and subdermal tissues caused by the yeast-like organism Lacazia loboi, which affects humans and Delphinidae. Cases of lobomycosis and lobomycosis-like disease (LLD), a disease very similar to lobomycosis but for which a histological diagnostic is missing, have been reported in small cetaceans from the Americas and Europe. Here we report on LLD in Indo-Pacific bottlenose dolphins Tursiops aduncus from the tropical lagoon of Mayotte, between Mozambique and Madagascar. From July 2004 to June 2008, boat surveys were conducted in Mayotte waters. At least 71 adult dolphins were photo-identified. Six (5 males, 1 female) had multiple raised, greyish nodules on the dorsal fin, head, flanks, belly, back and tailstock that suggested LLD. The lesions were extensive in some cases. The calf of the positive female was also affected. LLD has been present in this community since at least 1999. As sampling was not possible, the aetiology of the disease could not be explored. The emergence of LLD in Mayotte may be related to degradation of the coastal environment associated with rapid urbanization, expanding agriculture and increased release of untreated freshwater runoffs. Other skin lesions included scars, healing wounds, whitish lesions and lumps.
\end{abstract}

KEY WORDS: Indo-Pacific bottlenose dolphin $\cdot$ Tursiops aduncus $\cdot$ Skin diseases $\cdot$ Lobomycosis Mayotte $\cdot$ Indian Ocean

\section{INTRODUCTION}

Skin lesions have been described in odontocetes and mysticetes worldwide (Van Bressem et al. 2008). They may be caused by viruses, bacteria, fungi and protozoans and appear to be occurring more frequently in recent years (Van Bressem et al. 2008). Their emergence and severity seem, in some cases, to be related to natural and anthropogenic factors such as water quality degradation and inland water inputs (Wilson et al. 1999, Reif et al. 2006, Van Bressem et al. 2007, 2009).

Lobomycosis is a chronic mycotic disease of the skin and subdermal tissues caused by Lacazia loboi, an uncultivated pathogen that belongs, with the other dimorphic fungal pathogens, to the order Onygenales (Herr et al. 2001). The disease has been identified in humans who inhabit or have traveled to the Amazon Basin and in Delphinidae (common bottlenose dolphin Tursiops truncatus and Guiana dolphins Sotalia guianensis) from the US Atlantic coast, Brazil, Surinam and the Bay of Biscay in Europe (Caldwell et al. 1975, Symmers 1983, Van Bressem et al. 2007). Lobomycosis in Delphinidae is characterized by grayish, whitish to slightly pink, verrucuous lesions, which are often raised and may ulcerate and form plaques that sometimes reach more than $30 \mathrm{~cm}$ in their broadest dimen- 
sion (Migaki et al. 1971, Reif et al. 2008). In South America, a disease very similar to lobomycosis, but for which a histological diagnostic is missing, was recently reported in coastal $T$. truncatus from Colombia, Ecuador, Peru and Brazil as well as in S. guianensis from the Paranaguá estuary, Brazil (Van Bressem et al. 2007, 2009, Moreno et al. 2008). Lobomycosis and lobomycosis-like disease (LLD) have been mostly observed in tropical and equatorial areas, such as Florida and Texas in the US and Peru, Ecuador, Columbia, Venezuela, Surinam and Brazil in South America. The habitat of the pathogen is believed to be aquatic or associated with soil and vegetation. T. truncatus from the Indian River Lagoon, Florida, affected by lobomycosis, were found to have a significant impairment in adaptive immunity possibly related to chronic exposure to environmental stressors (Reif et al. 2008). The T. truncatus communities from South America presenting LLD inhabited biologically and chemically polluted waters surrounding large ports and cities (Van Bressem et al. 2007).

The Indo-Pacific bottlenose dolphin Tursiops aduncus is only found in the warm temperate to tropical Indo-Pacific Ocean, from South Africa in the west to southern Japan and central Australia in the east (Jefferson et al. 2008). It is the second most common cetacean species in the coastal waters of the inner lagoon of Mayotte (Comoros archipelago, northeast Mozambique Channel, SW Indian Ocean; Kiszka et al. 2007). Recent investigations have indicated that this species is resident in the lagoon of Mayotte, with a community size of $\geq 100$ individuals (Kiszka \& Pusineri 2006). Here we report on LLD and other skin diseases in $T$. aduncus from the tropical lagoon of the fast developing Mayotte, where human lobomycosis has not occurred or been diagnosed.

\section{MATERIALS AND METHODS}

Study area. Mayotte $\left(12^{\circ} 50^{\prime} \mathrm{S}, 45^{\circ} 10^{\prime} \mathrm{E}\right)$ is located in the northern Mozambique Channel between Madagascar and the African mainland (Fig. 1). It is composed of 2 major islands: Grande Terre, (approximately $360 \mathrm{~km}^{2}$ ) where most of the human population lives, and the smaller Petite Terre (approximately $13 \mathrm{~km}^{2}$ ) which is embedded in the barrier reef (Quod et al. 2000). Mayotte is almost entirely surrounded by a $197 \mathrm{~km}$ long barrier reef. Adjacent to the northern extent of the lagoon is the submerged reef complex of Iris Bank (approximately $215 \mathrm{~km}^{2}$ ). The inner lagoon ranks among the largest lagoons of the world (1100 $\mathrm{km}^{2}$, Quod et al. 2000), averaging $20 \mathrm{~m}$ in depth with deeper waters reaching $80 \mathrm{~m}$ to the west. Numerous deep passes are present in the barrier reef, many of which represent the beds of old rivers. The main island is surrounded by a fringing reef $(195 \mathrm{~km})$, discontinuous where river mouths open. Approximately 670 ha of mangrove forests occur on the main island, especially in protected bays (Quod et al. 2000).

Individual identification. From July 2004 to June 2008, small boat-based cetacean surveys were conducted between 07:00 and 18:00 $\mathrm{h}$ in Mayotte waters in sea conditions not exceeding Beaufort 3. Observation effort concentrated mostly on the lagoon and over the insular slope. A total of $904 \mathrm{~h}$ (185 d) were spent actively searching for marine mammals. When Tursiops aduncus were encountered, the following information was collected: group size (maximum, minimum and best estimate), group composition (adults, subadults and calves), activity and geographic position (Würsig \& Würsig 1977, Shane 1990). Calves were defined as individuals whose body length was onethird or less than that of other dolphins in the area and that usually remained close to their mothers in the infant position (Mann \& Smuts 1999, Mann et al. 2000). Adults were defined as large, robust dolphins.

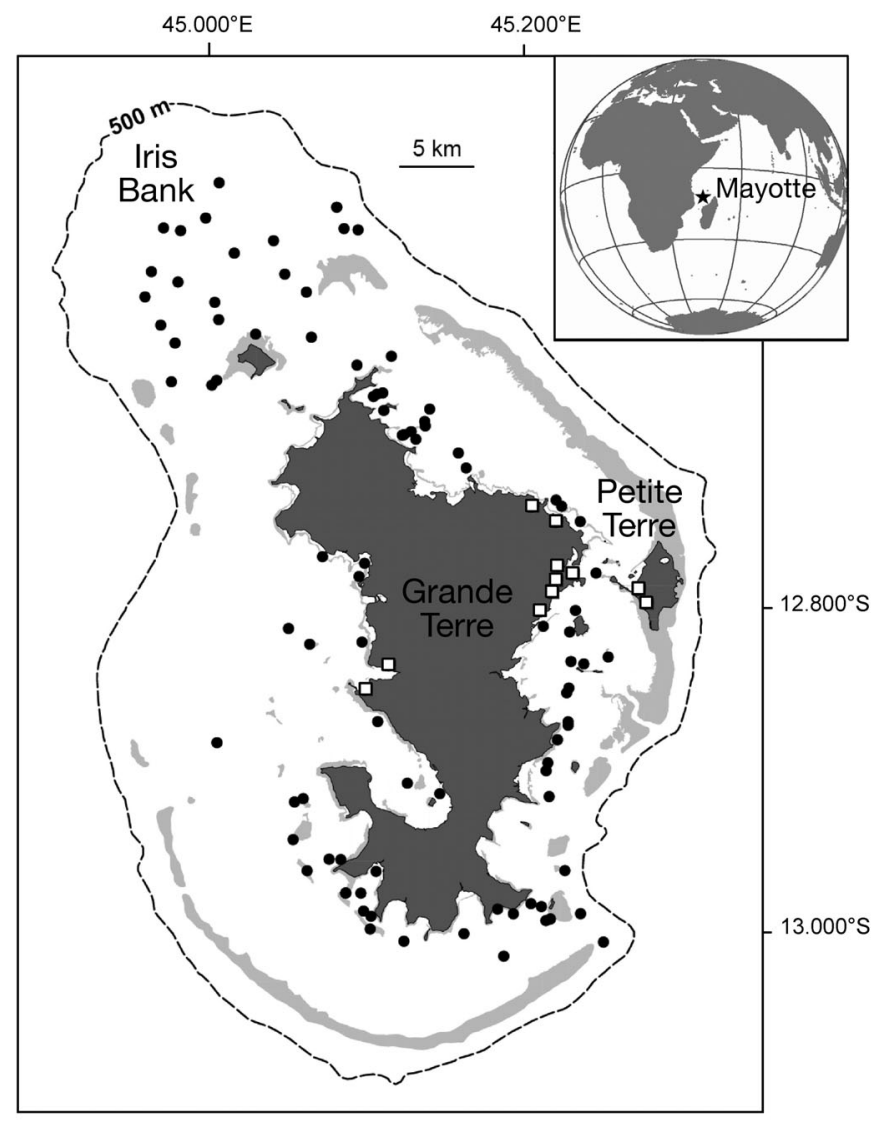

Fig. 1. Tursiops aduncus. Mayotte and the distribution of Indo-Pacific bottlenose dolphin sightings from July 2004 to June 2008. ๑: dolphin sightings from 2004 to 2008; $\square$ : major human settlements (>5000 inhabitants). Dark grey areas: land; light grey areas: coral reefs 
Attempts were made to photograph all individuals present in the group during each sighting. Colour photographs were taken with a $35 \mathrm{~mm}$ digital camera equipped with 100 to $300 \mathrm{~mm}$ lenses. All photographs were examined for quality, and only those of good quality (good focus and perpendicular to the photographer) were considered for subsequent analysis. When possible, the sex was determined during underwater observations or a posteriori using underwater images. Females were also identified on the basis of an accompanying calf.

Skin diseases. Good quality photographs of Tursiops aduncus taken from June 2004 to June 2008 were visually examined and every image showing individuals with skin lesions was extracted. Two types of lesions were defined: lobomycosis-like skin lesions and other skin lesions. The diagnosis of LLD followed Van Bressem et al. (2007), i.e. multiple firm, whitish to slightly pink nodules, often raised, that may ulcerate on the dorsal and pectoral fins, head, flanks, belly, back, flukes and caudal peduncle. Underwater images taken from August 2006 onwards were occasionally used to assess the extent and development of the disease and dolphin health status. We attempted to quantify the extent of skin lesions in individuals with LLD as a percentage of the whole body surface.

\section{RESULTS}

\section{Tursiops aduncus encounters and photo- identification}

From July 2004 to June 2008, Tursiops aduncus were encountered 91 times. It is the second most common species in the waters around Mayotte $(16 \%$ of all cetacean encounters, J. Kiszka \& C. Pusineri pers. obs.). Although having an inshore distribution around the island in the shallow waters of the vast Iris Bank open complex, this community may also be observed up to $20 \mathrm{~km}$ from the coast (Fig. 1). Group composition was variable: mixed groups (adults, subadults and calves) constituted $31 \%$ of sightings, mother-calf pairs $19 \%$, adults $31 \%$, adults with subadults $13 \%$ and subadults
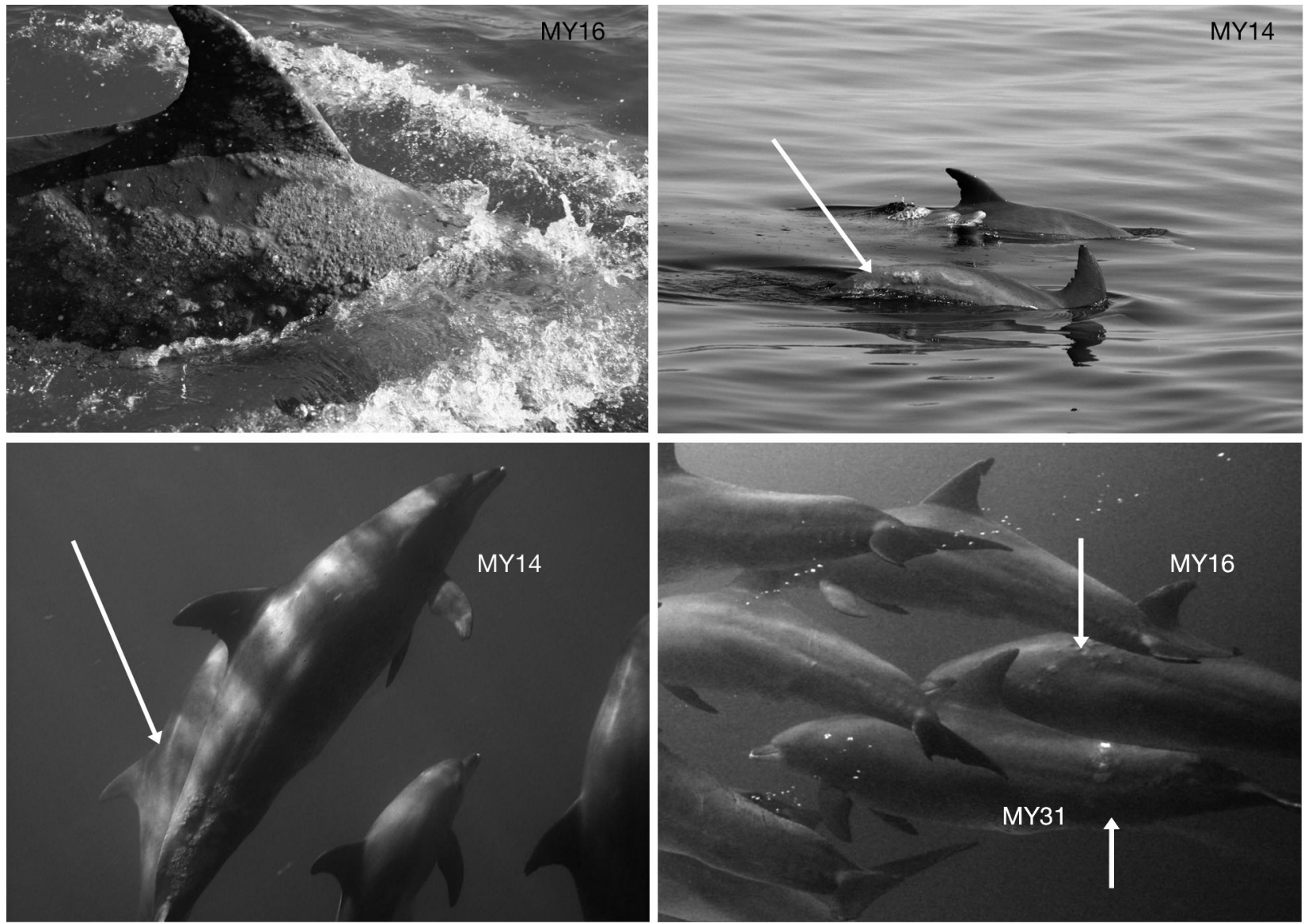

Fig. 2. Tursiops aduncus. Lobomycosis-like disease in dolphins around Mayotte. Photo credits: N. Bertrand, J. Kiszka and J. Wickel 
$6 \%$. Seventy-one adult individuals were photo-identified, $77 \%$ of which were recaptured at least twice.

\section{LLD macroscopic characteristics and epidemiology}

Six (5 males and 1 female) of the 71 photo-identified adult dolphins had multiple raised, greyish nodules on the dorsal fin, head, flanks, belly, back and tailstock resembling LLD (Fig. 2). Prevalence of the syndrome was $8.5 \%$. Males seemed more frequently affected than females. The approximately $1 \mathrm{yr}$ old calf of the positive female also featured similar gross cutaneous lesions. The mother-calf pair was first observed in December 2004 and last seen with LLD in December 2005. The calf has since disappeared and possibly died. The disease covered between 1 and $5 \%$ of the body surface in 2 apparently newly infected males (MY08 and MY30) to approximately $40 \%$ of the body surface in another adult male (MY16) (Table 1, Fig. 2). During the present study the disease clearly progressed in 3 adult males (MY16, MY30 and MY08, Table 1, Fig. 3) but not obviously so in the other individuals. MY16 already had extensive lobomycosis-like lesions on the back, right flank and dorsal fin in August 1999 (Sea Blue Safari pers. comm.). The disease had clearly progressed by December 2004 and continued so, though relatively slowly, until last observed in February 2008. Although MY08 and MY30 were photographed since 2004, LLD was not detected in these dolphins before September 2007 and May 2005, respectively. The lesions have since progressed in both specimens (Table 1, Fig. 3). Female MY05 has been reported around Mayotte since 1996 (Kiszka \& Pusineri 2006) but her disease was not noticed until the present study. None of the affected dolphins showed disease regression. LLD has likely been present in this community since at least 1999. Dolphins with LLD were not

Table 1. Tursiops aduncus. Details of Indo-Pacific bottlenose dolphins T. aduncus from the Mayotte lagoon affected by lobomycosis-like disease (LLD) and other skin conditions from 2004 to 2008. PBA: percentage of the body affected by skin lesions; DIP: disease progression; Unkn: unknown; nd: no data. Specimens are ordered by disease and extent of lesions

\begin{tabular}{|c|c|c|c|c|c|c|c|c|}
\hline Dolphin & Sex & $\begin{array}{l}\text { Age } \\
\text { class }\end{array}$ & $\begin{array}{l}\text { Dolphir } \\
\text { (dd. } \\
\text { First }\end{array}$ & $\begin{array}{l}\text { ounter } \\
\text { ly) } \\
\text { Last }\end{array}$ & LLD & PBA & DIP & Description \\
\hline MY30 & M & Adult & 29.12 .04 & 20.05 .08 & Yes & $<5 \%$ & Yes & $\begin{array}{l}\text { Raised, congregating, whitish to } \\
\text { greyish lesions on the dorsal fin, first } \\
\text { seen in May 2008; one single nodule } \\
\text { on the back }\end{array}$ \\
\hline MY14 & M & Adult & 03.08 .05 & 23.10 .05 & Yes & $\sim 10 \%$ & No & Raised, greyish lesions on tailstock \\
\hline MY05 & $\mathrm{F}$ & Adult & 14.12 .04 & 19.12 .05 & Yes & $\sim 10 \%$ & No & $\begin{array}{l}\text { Lesions seen on the back, below } \\
\text { dorsal fin }\end{array}$ \\
\hline MY31 & M & Adult & 29.12 .04 & 13.06 .05 & Yes & $<10 \%$ & No & Raised, greyish lesions on tailstock \\
\hline MY05_1 & Unkn & Calf & 14.12 .04 & 19.12 .05 & Yes & $\sim 20 \%$ & No & $\begin{array}{l}\text { Lesions on the back below dorsal fin } \\
\text { at first encounter; calf of MY05 }\end{array}$ \\
\hline MY40 & Unkn & Adult & 20.08 .04 & nd & Unkn & $<10 \%$ & Unkn & $\begin{array}{l}\text { Skin lumps on the back between the } \\
\text { blowhole and the dorsal fin, possibly } \\
\text { representing the beginning of LLD or } \\
\text { another mycotic disease }\end{array}$ \\
\hline MY02 & M & Adult & 26.08 .04 & 24.02 .06 & Unkn & $<10 \%$ & No & $\begin{array}{l}\text { Top of dorsal fin missing, } 2 \text { skin lumps } \\
\text { on dorsal fin, one close to the tip, } \\
\text { possibly representing the beginning } \\
\text { of LLD or another mycotic disease }\end{array}$ \\
\hline MY44 & F & Adult & 14.08 .04 & 17.02 .06 & No & $<5 \%$ & No & $\begin{array}{l}\text { Large, semi-circular scar below the } \\
\text { dorsal fin, possibly the remains of a } \\
\text { shark bite }\end{array}$ \\
\hline MY23 & Unkn & Adult & 11.09 .07 & 16.10 .07 & No & $>60 \%$ & No & $\begin{array}{l}\text { Healing wounds and scars on the } \\
\text { flanks and dorsal fin, some of which } \\
\text { were reminiscent of whitish velvety } \\
\text { lesions }\end{array}$ \\
\hline
\end{tabular}


segregated from the group with the possible exception of individual MY23, seen once at the periphery of a group of 8 , and another time alone.

\section{Other skin diseases}

Four other adult dolphins that apparently did not have LLD presented the following lesions (Fig. 4): (1) MY44: a large, semi-circular, white scar that may represent a healed shark bite; (2) MY23: several healing wounds and scars on the sides and dorsal fin, some of which were apparently infected and were reminiscent of whitish velvety lesions (Flach et al. 2008); (3) MY40 and MY02: skin lumps that may represent the beginning of LLD or another mycotic disease (Van Bressem et al. 2009) on the back or dorsal fin.

\section{DISCUSSION}

This is the first documented case of LLD in Tursiops aduncus and in the Indian Ocean. As no tissue samples were available for histopathological and molecular
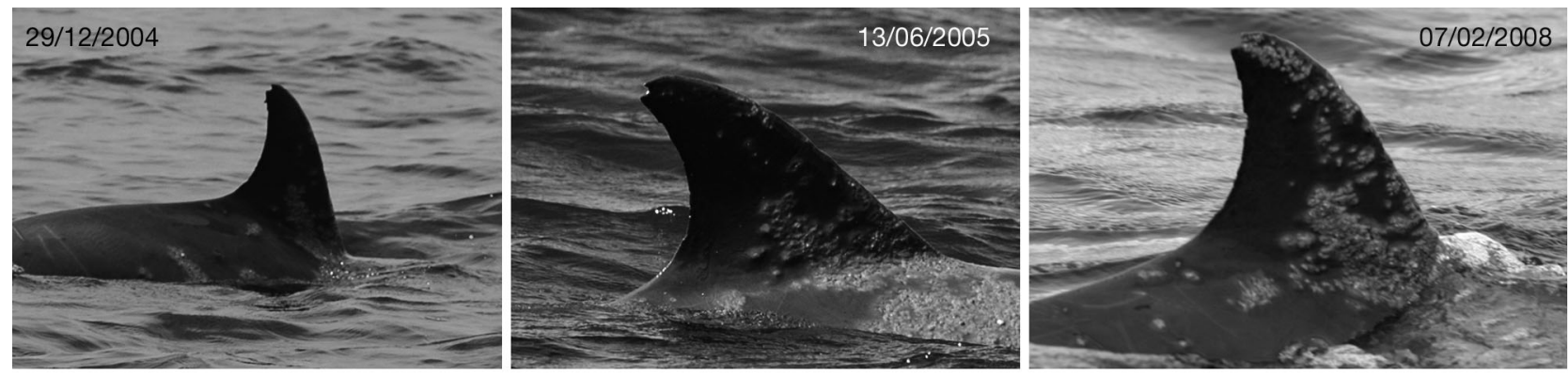

Fig. 3. Tursiops aduncus. Development of lobomycosis-like disease in male MY16 from December 2004 to February 2008
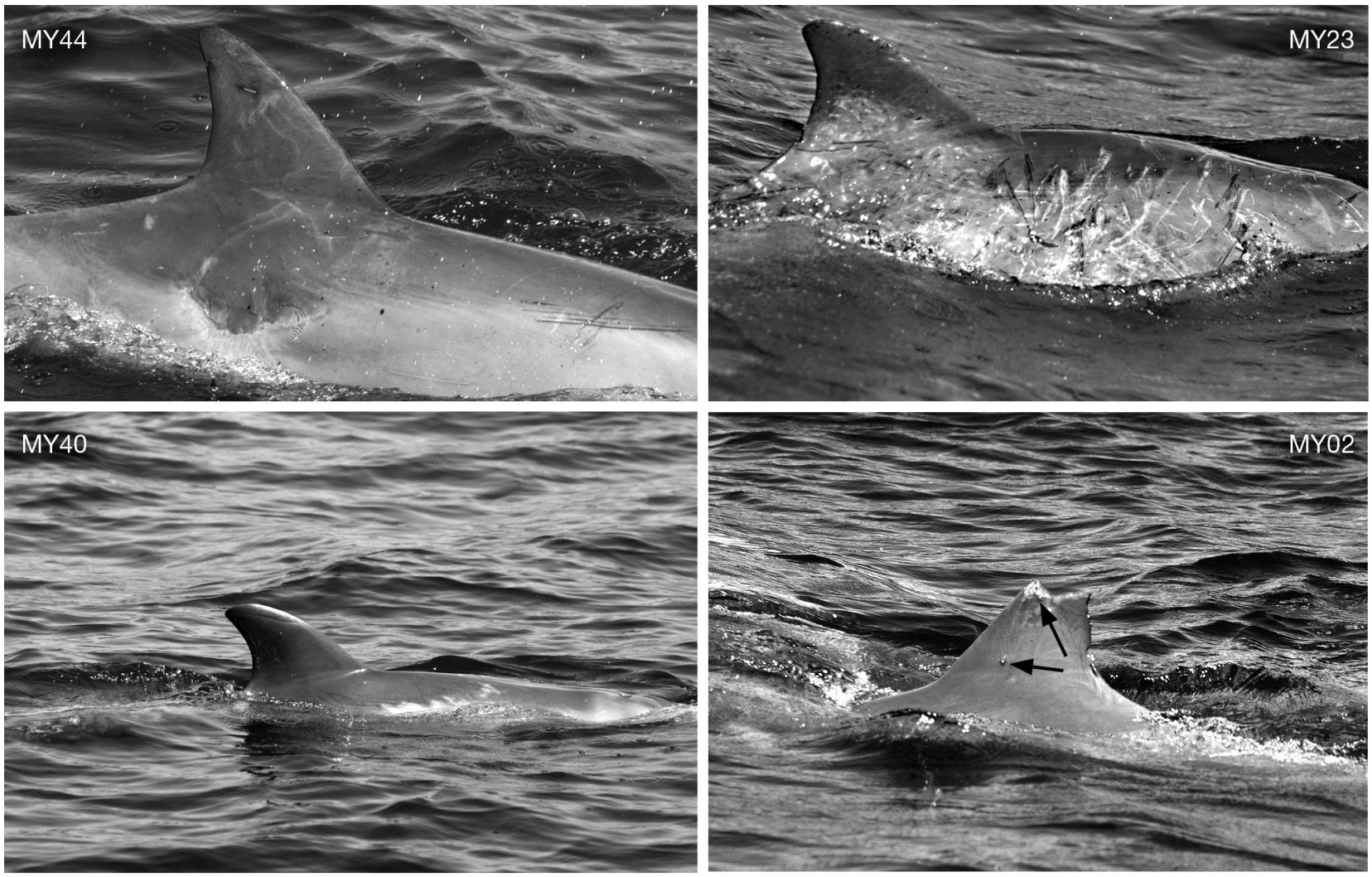

Fig. 4. Tursiops aduncus. Other skin lesions observed in dolphins around Mayotte. MY44: large semicircular scar, likely a healed shark bite; MY23: multiple scars and healing wounds, including several whitish lesions; MY40, MY02: skin lumps on the back and dorsal fin (arrows) - a large semicircular scar was also observed on the back of MY40 
analysis the aetiology of this disease remains unknown. However, in a previous study, all T. truncatus from Florida that were visually diagnosed with lobomycosis and further sampled for histology were positive for Lacazia loboi (Murdoch et al. 2008). The role of $L$. loboi as the aetiological agent of LLD was also confirmed by histology in a dead T. truncatus from the Tramandaí estuary, Brazil, visually diagnosed as positive when still alive (Van Bressem et al. 2007, Moreno et al. 2008). Chromoblastomycosis, a long-term fungal infection of the skin and subcutaneous tissue in humans that resembles lobomycosis in dolphins and may be caused by Cladophialophora carrionii, Fonsecaea pedrosoi and Phialophora verrucosa, has been reported in Madagascar and other islands from the Indian Ocean including Mayotte (Esterre et al. 1997, see also www.mycology.adelaide.edu.au/Mycoses/ Subcutaneous/Chromoblastomycosis). Whether these fungi may be related to the lobomycosis-like syndrome is unknown. Further studies will include sampling of the lesions and histological examination.

Prevalence of LLD in adults was $8 \%$ in the period 2004 to 2008, comparable with prevalence levels reported in Tursiops truncatus from the Indian River Lagoon, Florida (Reif et al. 2006, Murdoch et al. 2008). Males seemed to be more at risk than females but prevalence in each sex could not be calculated as sex could only be determined for a limited number of individuals. Whether this disease is endemic, epidemic, emerging or resurging is still unknown. Historic data indicate that it has been present in this community since at least 1999. The occurrence of 2 new cases (MY08 and MY30) during the study period suggests that the syndrome could affect more dolphins in the future. This is the second time that LLD has been observed in a calf. Until recently, LLD and lobomycosis had been mostly observed in large, presumably adult specimens. A Sotalia guianensis calf from the Paranaguá estuary, Brazil, had limited LLD in 2007 (Van Bressem et al. 2009), whereas the one observed during the present study had extensive lesions and disappeared 1 yr after being observed with LLD. His infected mother was likely the source of infection.

The emergence of LLD in Mayotte could be related to the degradation of the coastal environment. The human population has grown from 94410 inhabitants in 1991 to 186452 in 2007 (Institut National de la Statistique et des Études Economiques, Recensement Général de la Population, 2007), and urbanization is growing fast. Consequently, agriculture is increasing as well, and the release of untreated freshwater runoffs has increased in recent years. Further, the harbour has been developing quickly in the northeast and may have modified the biological and chemical composition of the marine environment. PCB levels in oysters Sac- costrea cucullata collected in the eastern portion of the lagoon, bordered by the largest urbanized areas, have increased significantly from 1997 to 2007 (from 14 to $24 \mu \mathrm{g} \mathrm{kg}{ }^{-1}$, dry weight) and unexplained important oyster mortalities have occurred (Thomassin et al. 2008). The relatively high prevalence of LLD and its extent in some animals may reflect environmental stress.

The apparent emergence of lobomycosis, LLD and other skin diseases in cetaceans worldwide in recent years, with apparently no previous records in wellstudied populations (Van Bressem et al. 2007, 2008, Moreno et al. 2008, Shirakihara et al. 2008), is worrying and should be further studied. Lobomycosis and LLD could have a negative impact on small, isolated coastal communities, such as Tursiops aduncus from Mayotte waters. The present study further suggests the role of coastal top predators, such as T. aduncus, as indicators of marine ecosystem health.

Acknowledgements. We thank the French Ministry of Environment (MEDAD) and the Collectivité Départementale de Mayotte for funding this work, conducted on behalf of the Marine Mammal Observatory (Direction de l'Agriculture et de la Forêt de Mayotte and Office National de la Chasse et de la Faune Sauvage), P. J. Ersts (American Museum of Natural History, Center for Biodiversity and Conservation) for providing the map of the study area, N. Bertrand and J. Wickel for providing some pictures of Indo-Pacific bottlenose dolphins from Mayotte and Sea Blue Safari for the underwater pictures of MY16 taken in 1999. M.F.V.B. was funded by Whale and Dolphin Conservation Society and CSI. Special thanks to G. Daudin for his help in the analysis of photo-identification data. Finally, we thank the 3 anonymous reviewers for their helpful and constructive comments.

\section{LITERATURE CITED}

Caldwell DK, Caldwell MC, Woodard JC, Ajello L, Kaplan W, McLure HM (1975) Lobomycosis as a disease of the Atlantic bottlenose dolphin (Tursiops truncatus, Montagu 1821). Am J Trop Med Assoc 24:105-114

Esterre P, Andriantsimahavandy A, Raharisolo C (1997) Natural history of chromoblastomycosis in Madagascar and the Indian Ocean. Bull Soc Pathol Exot 90:312-317

Flach L, Van Bressem MF, Reyes JC, Echegaray M and others (2008) Miscellaneous skin lesions of unknown aetiology in small cetaceans from South America. Paper SC/60/DW4 presented to the IWC Scientific Committee, Santiago, Chile, 30 May-27 Jun 2008. IWC, Cambridge. Available at www.iwcoffice.org/_documents/sci_com/SC60docs/SC-60DW4.pdf

> Herr RA, Tarcha EJ, Taborda PR, Taylor JW, Ajello L, Mendoza L (2001) Phylogenetic analysis of Lacazia loboi places this previously uncharacterized pathogen within the dimorphic Onygenales. J Clin Microbiol 39:309-314

Jefferson TA, Webber MA, Pitman RL (2008) Marine mammals of the world: a comprehensive guide to their identification. Academic Press, San Diego, CA

Kiszka J, Pusineri C (2006) Les delphinidés autour de Mayotte: structure des groupes, distribution, abondance et 
budgets d'activité. Rapport d'étude 2005-2006. Observatoire des Mammifères Marins de Mayotte (Direction de l'Agriculture et de la Forêt)

Kiszka J, Ersts PJ, Ridoux V (2007) Cetacean diversity around the Mozambique Channel island of Mayotte (Comoros archipelago). J Cetacean Res Manag 9:105-109

- Mann J, Smuts B (1999) Behavioral development of wild bottlenose dolphin newborns. Behaviour 136:529-566

> Mann J, Connor RC, Barre LM, Heithaus MR (2000) Female reproductive success in bottlenose dolphins (Tursiops sp.): life history, habitat, provisioning, and group-size effects. Behav Ecol 11:210-219

Migaki G, Valerio MG, Irvine B, Garner FM (1971) Lobo's disease in an Atlantic bottle-nosed dolphin. J Am Vet Med Assoc 159:578-582

Moreno IG, Ott PH, Tavares M, Oliveira LR and others (2008) Mycotic dermatitis in common bottlenose dolphins (Tursiops truncatus) from southern Brazil, with a confirmed record of lobomycosis disease. Paper SC/60/DW1 presented to the IWC Scientific Committee, Santiago, Chile, 30 May-27 Jun 2008. IWC, Cambridge. Available at www.iwcoffice.org/_documents/sci_com/SC60docs/SC-60DW1(colour).pdf

Murdoch ME, Reif JS, Mazzoil M, McCulloch SD, Fair PA, Bossart GD (2008) Lobomycosis in bottlenose dolphins (Tursiops truncatus) from the Indian River Lagoon, Florida: estimation of prevalence, temporal trends, and spatial distribution. EcoHealth 5:289-297

Quod JP, Naim O, Abdourazi F (2000) The Comoros archipelago. In Sheppard C (ed) Seas at the Millennium: an environmental evaluation. Pergamon Press, Oxford, p 243-252

Reif JS, Mazzoil MS, McCulloch SD, Varela RA, Goldstein JD, Fair PA, Bossart G (2006) Lobomycosis in Atlantic bottlenose dolphins from the Indian River Lagoon, Florida. J Am Vet Med Assoc 228:104-108

Reif JS, Peden-Adams MM, Romano TA, Rice CD, Fair PA, Bossart GD (2008) Immune dysfunction in Atlantic bottlenose dolphins (Tursiops truncatus) with lobomycosis. Med Mycol 47:125-135

Shane SH (1990) Behavior and ecology of the bottlenose dol-

Editorial responsibility: Michael Moore,

Woods Hole, Massachusetts, USA phin at Sanibel Island, Florida. In: Leatherwood S, Reeves $\mathrm{R}$ (eds) The bottlenose dolphin. Academic Press, San Diego, CA, p 245-265

Shirakihara M, Amano M, Van Bressem MF (2008) Skin lesion in a resident population of Indo-Pacific bottlenose dolphins in Japan. Paper SC/60/DW6 presented to the IWC Scientific Committee, Santiago, Chile, 30 May-27 Jun 2008. IWC, Cambridge. Available at www.iwcoffice.org/ _documents/sci_com/SC60docs/SC-60-DW6.pdf

Symmers WS (1983) A possible case of Lobo's disease acquired in Europe from a bottle-nosed dolphin (Tursiops truncatus). Bull Soc Pathol Exot Fil 76:777-784

Thomassin BA, Garcia F, Lagadec V, Sarrazin L and others (2008) Mayotte: évaluation de la qualité des eaux côtières du lagon à partir des polluants dosés dans les huîtres médiolittorales (octobre - novembre 2007). Report of GIS LagMay, Direction de l'Agriculture et de la Forét de Mayotte, Momoudzou

Van Bressem MF, Van Waerebeek K, Reyes JC, Félix F and others (2007) A preliminary overview of skin and skeletal diseases and traumata in small cetaceans from South American waters. Lat Am J Aquat Mamm 6:7-42

Van Bressem MF, Van Waerebeek K, Flach L, Reyes JC and others (2008) Skin diseases in cetaceans. Paper SC/60/DW8 presented to the IWC Scientific Committee, Santiago, Chile 30 May-27 Jun 2008. IWC, Cambridge. Available at www.iwcoffice.org/_documents/sci_com/ SC60docs/SC-60-DW8.pdf

> Van Bressem MF, Santos MO, Oshima JE (2009) Skin diseases in Guiana dolphins (Sotalia guianensis) from the Paranaguá estuary, Brazil: a possible indicator of a compromised marine environment. Mar Environ Res 67:63-68 doi:10.1016/j.marenvres.2008.11.002

> Wilson B, Arnold H, Bearzi G, Fortuna CM and others (1999) Epidermal diseases in bottlenose dolphins: impacts of natural and anthropogenic factors. Proc R Soc Lond B Biol Sci 266:1077-1083

> Würsig B, Würsig M (1977) The photographic determination of group size, composition, and stability of coastal porpoises (Tursiops truncatus). Science 198:755-756

Submitted: November 11, 2008; Accepted: January 21, 2009 Proofs received from author(s): March 24, 2009 